\title{
GROWTH AND FLOWERING OF ENDEMIC WILD LIBYAN GEOPHYTE, CYCLAMEN ROHLFSIANUM ASCHER, WITH A HIGH ORNAMENTAL VALUE
}

\author{
Khalafalla, M. M. ${ }^{1}-$ Menesy, F. $^{1}-$ MagouZ, M. R. ${ }^{2}-$ HAmed, E. B. ${ }^{3 *}$ \\ ${ }^{1}$ Hort. Dept., Fac. Agric., Kafrelsheikh Univ., Kafrelsheikh 33516, Egypt \\ ${ }^{2}$ Hort. Res. Inst., Agric. Res. Center, Giza, Egypt \\ ${ }^{3}$ Hort. Dept., Fac. Agric., Al-Bieda Univ., El Bieda, Libya \\ *Corresponding author \\ e-mail: Eman.B.A.Hamed@gmail.com
}

(Received 31 ${ }^{\text {st }}$ Dec 2019; accepted $6^{\text {th }}$ May 2020)

\begin{abstract}
Seeds of Cyclamen rohlfsianum showed high germination percentage ( $88 \pm 4 \%)$, followed by a rapid development of the fat hypocotyl during 29-35 days of growth and the lastly, one leafy cotyledon emerged from the seed coat. In the present study we measured the annual increments of leaves and tuber size in seedlings of the common geophyte ornamental perennial endemic Libyan, C. rohlfsianum, predicted by shrubs in their native habitat, over 6-year growing period. The results showed that the tuber fresh weight and diameter varied with the age of the plants, depending on the leaf number and area. These slowly increased for the first 3 years, then at a more rapid rate for the following 2 years with the highest reached at 6 years. Flowering did not occur until number of leaves and total leaf area were at least 3 and $49 \mathrm{~cm}^{2}$, respectively. The vegetative tuber size of $6.15 \mathrm{~g}$ fresh weight and $2.8 \mathrm{~cm}$ diameter, (4-year-old plants) were probably large enough to produce, in the next year $\left(5^{\text {th }}\right.$ year of growing period), three or more flowers $(3.5 \pm 0.9)$ and thereafter, more than three leaves emerged (3.76) whereas, $79 \pm 3.5 \%$ of plants flowered. However, flowering tuber size sharply increased to $21.27 \mathrm{~g}$ and $5.49 \mathrm{~cm}$, respectively for 6year-old plants, which were associated with increases in flowering percentage $(98 \pm 7 \%)$, number of flowers $(4.3 \pm 0.4)$ and total leaf area $\left(111.78 \mathrm{~cm}^{2}\right)$.
\end{abstract}

Keywords: germination, seedling growth, flowering tuber size, hysteranthous, floral trunks

\section{Introduction}

The genus Cyclamen L. (Myrsinaceae formerly Primulaceae) consists of 22 species (Grey-Wilson, 2002), which are distributed in and near the Mediterranean region and western Asia. It is an attractive plant with potential as a commercial flowering pot plant and garden plants (Dole and Wilkins, 2005). Although cyclamens are dicotyledonae, the embryo consists of only a single cotyledon (pseudomonocotyledonae) (Le Nard and De Hertogh, 1993a).

Cyclamen is classified either according to the flowering periods or by their growth cycle. Flowering periods vary with the species, but can be divided into two groups: autumn flowering $(C$. africanum, $C$. cilicicum, $C$. graecum, $C$. cyprium, $C$. hederifolium, and C. rohlfsianum) and spring flowering (C. balearicum, C. orbiculatum, $C$. persicum, $C$. pseudibericum, and $C$. repandum). The growth cycle classification is based on the appearance of the flowers and leaves. Group 1, the synanthous growth, in which flowering occurs after the appearance of leaves, e.g., C. persicum. In group 2, the hysteranthous growth, in which flowering occurs before leaf emergence, e.g., $C$. rohlfsianum, C. cilicicum. 
A tetraploid Cyclamen rohlfsianum (Sibusawa and Ogawa, 1997; Grey-Wilson, 2002 ) is endemic to Al-Jabal Al-Akhdar and locally known as "Racuf" (El-Darier and El-Mogaspi, 2009). It is one of the most beautiful ornamental perennial geophytes in Libya. Such tetraploid cyclamen $(2 n=4 x=96)$ offers useful opportunities to produce new varieties from which can be improve this crop.

Environmental conditions, especially temperature, control annual development and florogenesis in geophytes (Le Nard and De Hertogh, 1993b). Autumn flowering Cyclamen of the Mediterranean region are adapted to warm environmental conditions (tender plants). Therefore, tubers flowering in September-November before leaf emergence, when soil temperature decreases. Thereafter, leaves grow and accumulate metabolic reserves throughout the wet and cool season (autumn to spring), until the dormancy period, which begins in late spring. Hence, during summer the flowers initiation and differentiation occur in the mature tubers (Rees, 1992; Le Nard and De Hertogh, 1993b).

Extensive studies have been conducted for elucidation of the growth habit, flowering and production of commercially important C. persicum (Sundberg, 1981a, b, 1982; Karlsson and Werner, 2001; Takamura, 2007; Oh et al., 2008) while, little is known for most other species in this genus (Affre and Thomson, 1999; Muftuoglu et al., 2009; Seyring et al., 2009; Lazarevic and Lazarevic, 2010; Jalali et al., 2012; Curuk et al., 2015, 2016; Mammadov et al., 2016). In addition, no precise information is available for wild tuber of $C$. rohlfsianum (Grey-Wilson, 2002).

In natural conditions, observations reported that $C$. rohlfsianum is grown in welldrained soil and prefers shady locations (shade of sheltering rocks or bushes). Leaves are rounded to kidney-shaped, (usually hearted in young plants), sometimes toothed or broadly triangular lobed, deep green, to $12 \mathrm{~cm}$ diameter, patterned pale grey or silvery green patterns above, and purplish red below (Fig. 1). The leaves have long, brownishpurple petioles arising from the crown $(12-25 \mathrm{~cm})$.

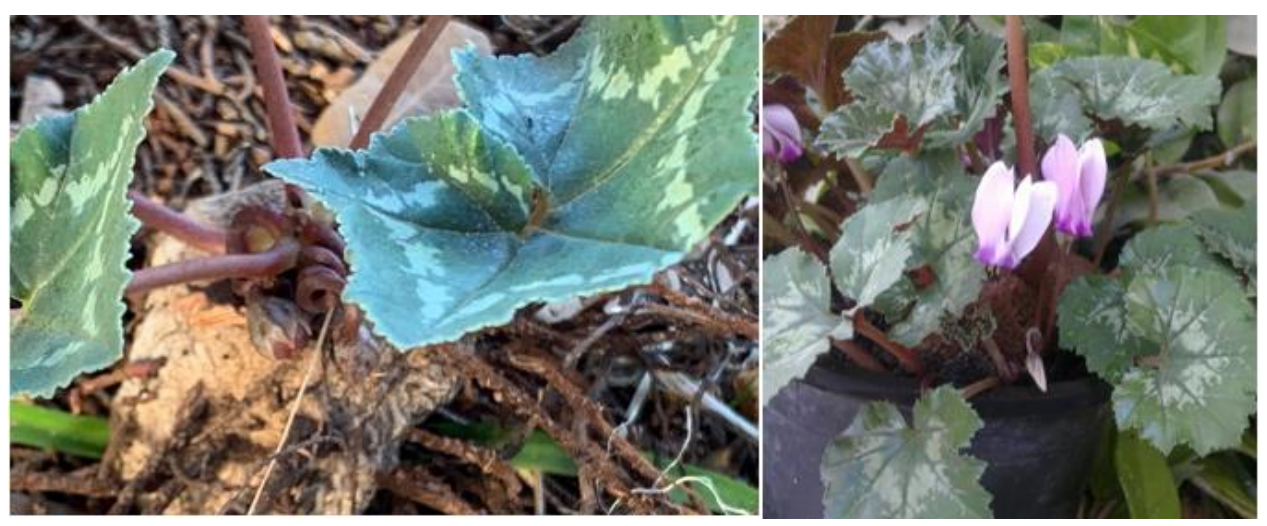

Figure 1. The leaves broadly triangular lobes, toothed margin, deep green above with pale grey blotch marks. Right: note leaf emergence after flowering, sometimes one or two flowers appearing with the mature leaves. Left: not the new fruit capsule, drawn down to the soil surface by the coiling of the pedicel

The pink flowers of $2.5-3.5 \mathrm{~cm}$ long (Fig. 2), are solitary on leafless scapes (pedicels) $6-13 \mathrm{~cm}$ in height, each have five reflexed petals, sometimes twisted, whose bases constitute a short tube, with deep maroon mouth 'eye' and projecting anthers (1.0- 
$1.5 \mathrm{~cm})$. The fruit is a capsule, drawn down to the soil surface by the coiling of the pedicel to release the rip dark brown and dry seeds (Fig. 3).

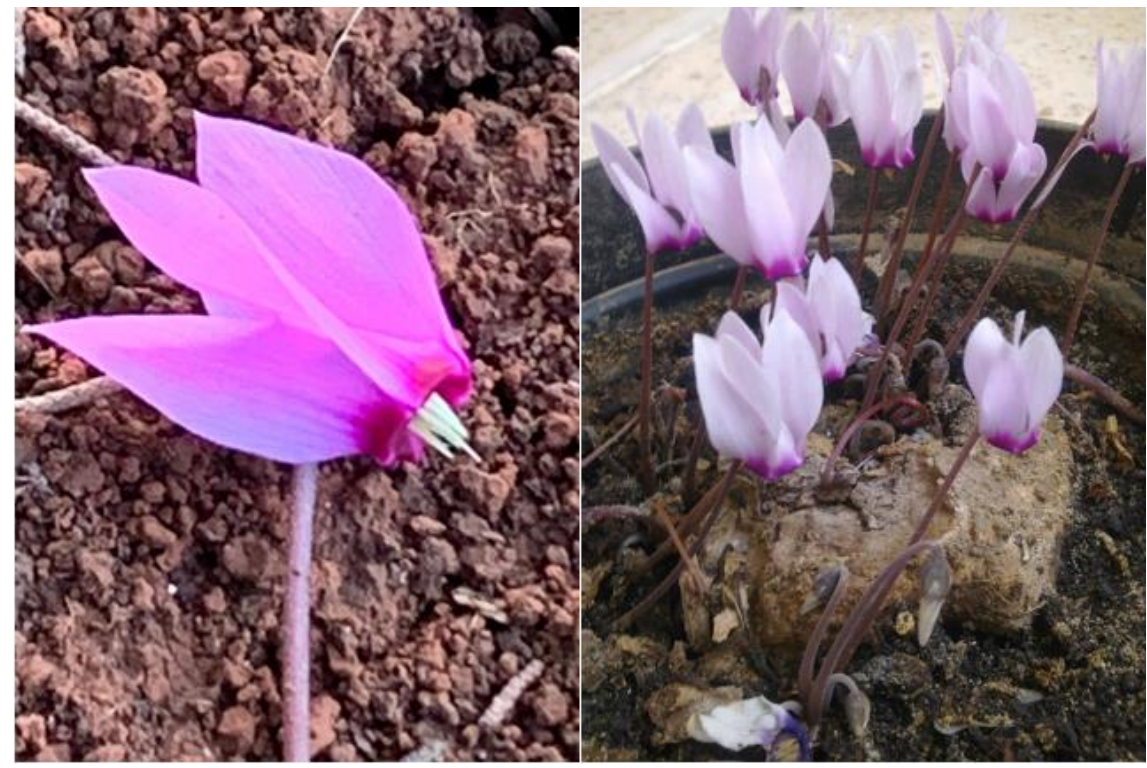

Figure 2. The mature tuber, nodding flowers arise from several growing points (right) in September-November before leaf emergence, note pink flowers, with deep maroon mouths and the stamen cone with long style protruding from the mouth of the corolla (left)

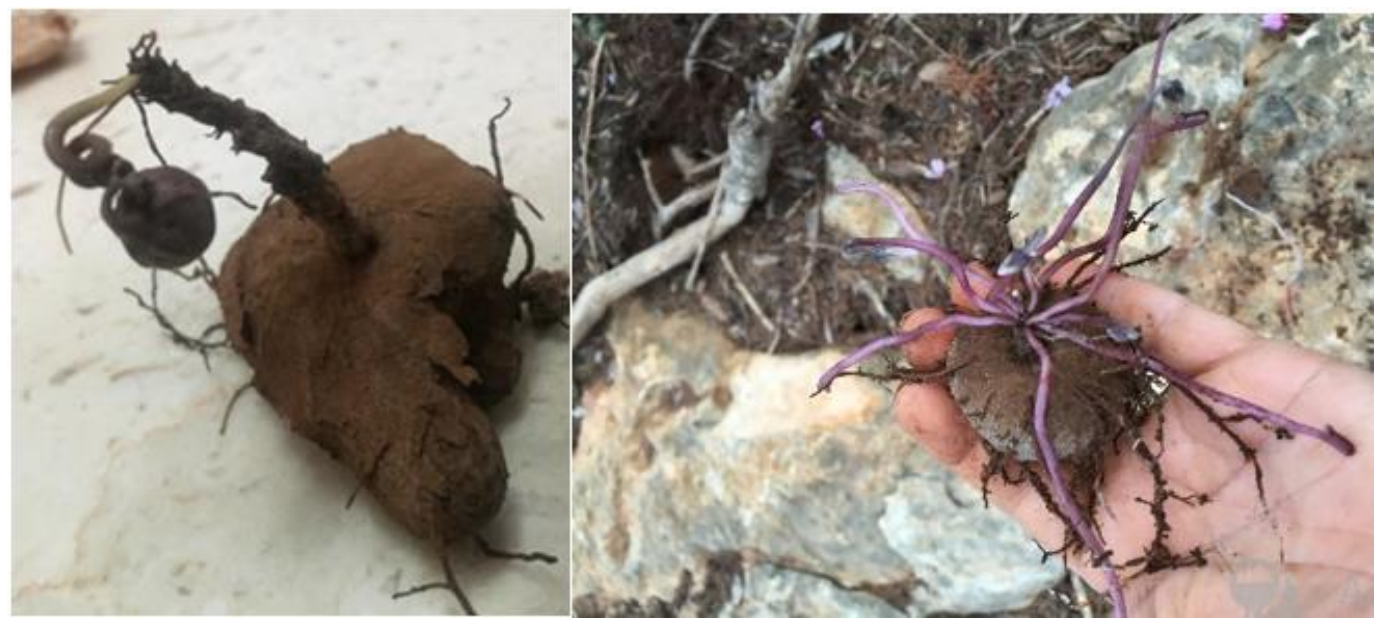

Figure 3. The tuber grows among rocks and beneath bushes in the wild, it has a depression in the top and roots produced from sides and the center of the bas, note the ten flowers appearing from one growth point of 6-year-old tuber (right). The fruit capsule on tightly coiled pedicel at the top of floral trunk (left)

The tuber is generally large and corky fleshy and continue to enlarge laterally every year. The size of mature tubers can reach more than $30 \mathrm{~cm}$ in diameter. It is more or less globose in form, often regular and becomes very irregular by time and consists of several swollen legs joined together by narrower 'necks' of tissue. Young tubers generally have a single growing point on the upper surface (those producing flowers and 
leaves), but as they age the growing point divides and may eventually end up well separated and confined on the upper surface of the tubers. Some mature tubers produced slender woody necks (these are called floral trunks) by elongation of the growing points, which have the flowers and leaves at the tip (Figs. 3 and 4); though it is often associated with plants that grow in rather rocky soils, especially in woodland or on screes. It happens also, when the growing points become widely spaced and the tubers become increasingly irregular, especially when they become squeezed between rocks. Roots are produced at the base and lower sides of the tuber (Widmer, 1992; Le Nard and De Hertogh, 1993a; Grey-Wilson, 2002).

The growth of goephytes is generally considered to be quite slow and usually need to reach a certain size before they can be used for flowering pot plant production (Le Nard and De Hertogh, 1993b). Therefore, during six consecutive years, this study initiated to determine the period from sowing to flowering tuber of Cyclamen rohlfsianum under the native habitat.

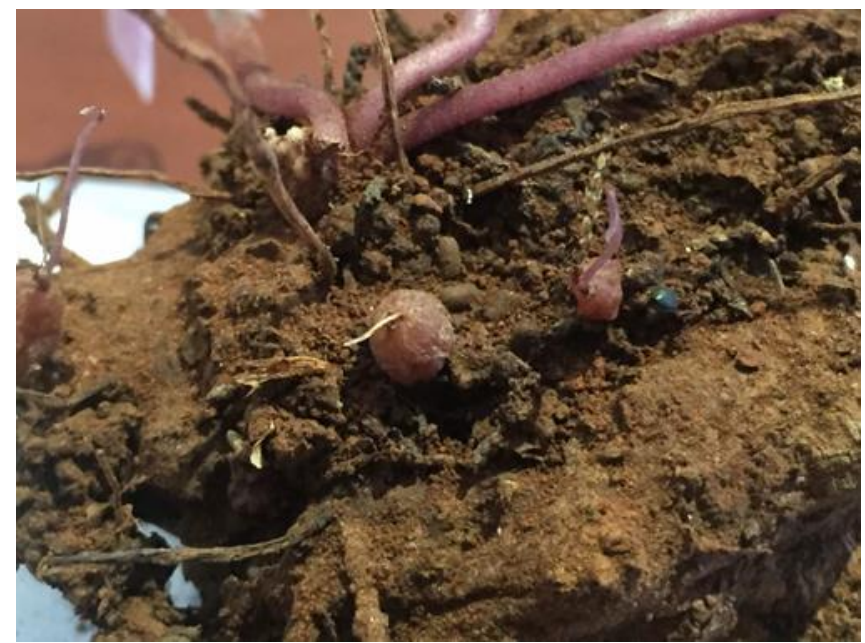

Figure 4. Cyclamen rohlfsianum self-sown, Al-Jabal Al-Akhdar, East of Libya, where it is a common wild plant (note three seedlings)

\section{Materials and methods}

The present research was conducted at the laboratory of Department of Horticultural, Faculty of Agriculture, Omar Al-Moukhtar University, Al-Bieda for the laboratory experiments, but the field experiments were carried out in private farm at Al-Bieda located at Al-Jabal Al-Akhdar region, Libya $\left(30^{\circ} 33^{\prime} \mathrm{N}\right.$ latitude and $20^{\circ} 25^{\prime} \mathrm{E}$ longitude at an altitude $590 \mathrm{~m}$ above the mean sea level). Mean monthly temperature, and rainfall at the study site for 6 years (2014-2019) were recorded daily at the Shahat meteorological station (Fig. 5).

\section{Germination and seedling growth}

Seeds of $C$. rohlfsianum used in the present study were collected between March and April 2013, before the leaves begin to be yellow, separated and stored at $4{ }^{\circ} \mathrm{C}$ until sown in early September. They were washed three times with a tap water and sown into plastic trays with 200 of $3 \times 3 \mathrm{~cm}$ cells filled with a mixture of vermiculite and peat $(1: 1$ by volume). The trays were placed at a private nursery greenhouse and covered with 
black polyethylene sheet until commencement of germination, where the minimum temperature was maintained at $15{ }^{\circ} \mathrm{C}$.

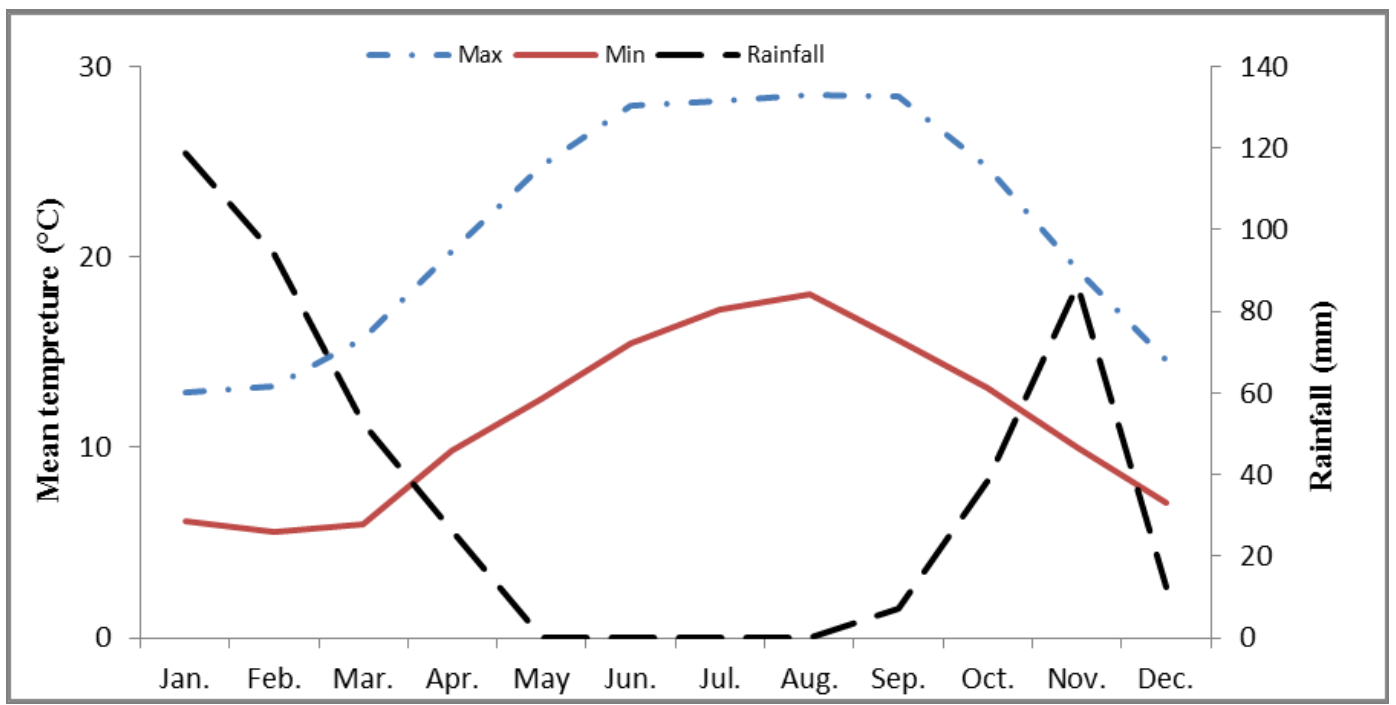

Figure 5. Monthly rainfall and air temperature. Air temperature represents the average daily maxima (Max) or daily minima (Min) during the study period (2014-2019)

The seed germination criterion was noticed as visible protrusion on the surface of soil at least $0.5 \mathrm{~cm}$ of the expanded hypocotyl of seedling. Germination was noted periodically every week from the date of sowing and continued till the germination ceased with final germination percentages recorded by using three replicates, each replicate contained 2 trays.

For studying the characteristics of seed germination during imbibition period, seeds were germinated in $9 \mathrm{~cm}$ petri dishes on moistened filter paper placed in dark place at room temperature of $22 \pm 2{ }^{\circ} \mathrm{C}$. Three replicates of 25 seeds per dish were used. Number of days from sowing to commencement of germination during imbibition period (emergence of the radicle), elongation of the hypocotyl, initial development of the primary root, protrusion the cotyledon blade and germination period were recorded.

Data for germination and seedling growth were expressed as mean \pm standard deviation for 18 measurements in each replicate.

\section{Field studies}

To determine the period from seed germination to flowering tuber Cyclamen rohlfsianum under field conditions, 65-day-old seedlings were transplanted from trays to their native habitat protected by shrubs (Pistacia lentiscus and Juniperus phoenicia). The seedlings were planted in fine tilth soil (well-drained, dark reddish brown and friable clay soils) at a depth of 1.5 to $2 \mathrm{~cm}$ in the three growing beds of $1.5 \times 3 \mathrm{~m}$, approximately $0.5 \mathrm{~m}$ apart between beds. The spacing and density used were $15 \mathrm{~cm}$ between seedlings with 10 seedlings in a single row, respectively. Light intensity in the planes of plants beneath bushes averaged about $47 \mathrm{klx}$, during most of the growing season (measured with a light meter, ST-85 Auto-range illuminance meter, Beijing, China). In addition to natural rainfall, (between October and April; Fig. 5), plants were irrigated in October-November and March-April once every 10 days. 
Soil samples were collected at random from the site, air-dried, crushed and analyzed for chemical properties according to Jackson (1967) (0.25\% total N, 10.96 ppm available $\mathrm{P}, 17.21 \mathrm{ppm}$ available $\mathrm{K}, 4.79 \%$ calcium carbonate and $6.48 \%$ organic matter). The $\mathrm{pH}$ and electrical conductivity of the soil solution prepared by diluting the soil with water $(1: 1, \mathrm{v} / \mathrm{v})$ were measured using digital $\mathrm{pH}$ and EC meters (7.8 and $0.75 \mathrm{mS} / \mathrm{cm}$, respectively). Seedlings were monthly fertilized once with $200 \mathrm{~g} / \mathrm{bed}$ kristalon (19N:19P:19K) beginning from the second year from October till April.

During six consecutive years, vegetative parameters were recorded in early March when leaves were still green (length of leaf petioles $(\mathrm{cm})$ and total leaf area $\left(\mathrm{cm}^{2}\right)$ and number). The total leaf area was measured with, CI-202 laser area meter, made in USA. Sixty tubers (two rows for each bed) were harvested in mid-May, after leaf yellowing. The medium was washed off roots and the expanded hypocotyl (stem tuber) then fresh weight $(\mathrm{g})$ and diameter $(\mathrm{cm})$ of tuber were determined.

After 5 years from sowing, when flowering occurred in September-November, percentage of flowering, number of flowers per plant and length of flower pedicels (cm) (at first reflexed petal) were recorded.

The experiment was arranged in randomized complete block design, as included 6 years each consisted of 20 plants and replicated three times. Data were analyzed using analysis of variance and means were compared according to Duncan's multiple range test at 0.05 level (Snedecor and Cochran, 1980).

\section{Results}

\section{Germination and seedling growth}

Seeds of $C$. rohlfsianum showed high percentage of germination. Although at 26 days (imbibition period) germination was $37 \pm 3 \%$, (radicle emergence) thereafter, becomes increasingly evident until maximum germination, of $88 \pm 4 \%$, was reached after approximately 32 days from sowing (total germination period).

After seeds germinate, the radicle extended within 26-32 days from seeding and a definite swelling on the hypocotyl became apparent during 29-35 days. The great increase in length during this period resulted from a rapid elongation of the hypocotyl and the initial development of the primary root. The hypocotyl was several times larger in diameter $(3.2 \pm 0.3 \mathrm{~mm})$ than the radicle. The primary root at this age was well developed and was $2.5 \pm 0.5 \mathrm{~cm}$ long with one or more lateral roots (Fig. 6).

At 9 days (after the hypocotyls were apparent) the one leafy cotyledon showed rapid elongation and remained tightly coiled in seed coat. Thereafter, at 13 days, the cotyledons had uncoiled and rapid increase in length to maximum elongation of $2.6 \pm 0.4 \mathrm{~cm}$, during 5 days.

\section{Field studies: leaf and tuber development and flowering}

Changes in leaf number and total leaf area of plants (planted under the nurse shrubs in the field) were monitored over a 6-year growing period to flowering.

Number of leaves on plant (Fig. 7) was assumed to be constant during the first 3 years of growth (1.16-2.0 leaves), whereas 4, 5 and 6-year-old ones have three or more leaves and reached a maximal (4.21) at six year-old plants, which was significantly the largest over the past 5 years. 


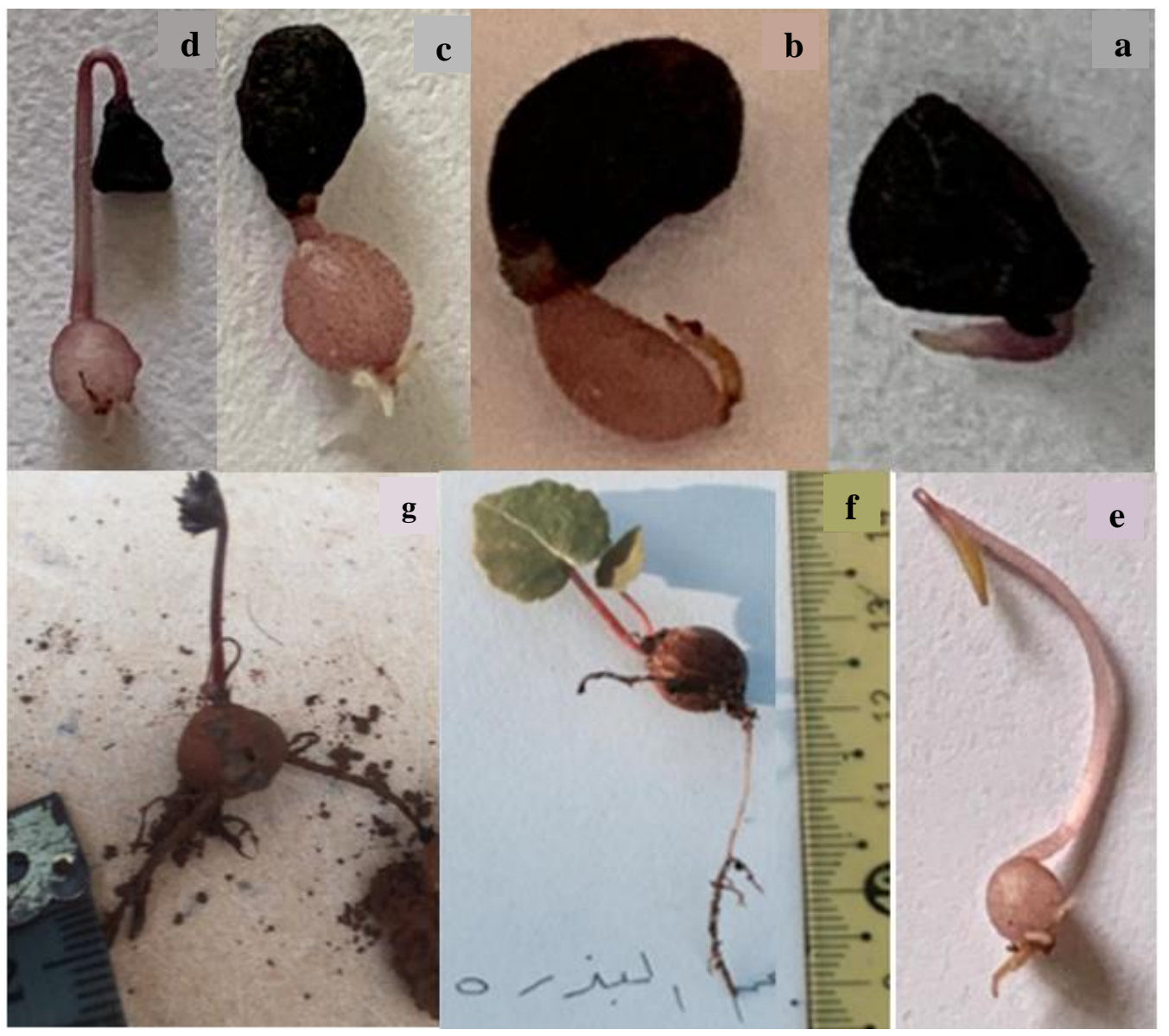

Figure 6. Germination and seedling of Cyclamen rohlfsianum. $a$ : The radicle extended with 26 days after the seeds were moistened, $b:$ A short, fat hypocotyl (tiny tuber) became apparent during 29 days (note the cotyledon still tightly coiled in the seed coat), $c$ : The initial development of the primary roots, 30 days after sowing, $d$ : The cotyledon remain tightly coiled in the seed coat and rapid increased in length to approximately 3-fold that of the hypocotyl, e: A seedling in which the only one leafy cotyledon has just expanded after 42 days, $f:$ A 6-month-old seedling that has one leafy cotyledon and one true leaf (note cotyledon closely resembles the heart-shaped true leaf), tiny tuber and primary root, g: A 1-year-old plant with new leaf emergence in autumn

Total leaf area and petiole length were significantly gradually increased during the 6year growing period, and reached a maximal $\left(111.78 \mathrm{~cm}^{2}\right.$ and $13.33 \mathrm{~cm}$, respectively) for 6-year-old plants (Fig. 7).

The tuber fresh weight and diameter significantly varied with age of the plants, depending on number of leaves and total leaf area. However, there were nonsignificant differences in both tuber fresh weight and diameter between the 2- and 3-year-old plants. At the end of $4^{\text {th }}$ year growing period, tuber fresh weight and diameter were significantly higher than the first 3 years of growing period and progressively increased as the growing period became longer, whereas they were $10.97 \mathrm{~g}$ and $3.88 \mathrm{~cm}$ at 5 -yearold plants and $21.27 \mathrm{~g}$ and $5.49 \mathrm{~cm}$, respectively at 6-year-old plants (Fig. 8).

The increase in tuber fresh weight and diameter were affected more by total leaf area than by leaf number (Fig. 7). The increase in total leaf area from $25.88 \mathrm{~cm}^{2}$ for a 3 -yearold plants to $49.00 \mathrm{~cm}^{2}$ for 4-year-old ones increased the tuber fresh weight and 
diameter by 2.87 and 1.43 -fold respectively, then sharply increased, with a further increase in total leaf area to 74.68 and $111.78 \mathrm{~cm}^{2}$ in five and 6-year-old plants, respectively, (by about 5.13, 1.98-fold and 9.94, 2.80-fold, respectively).

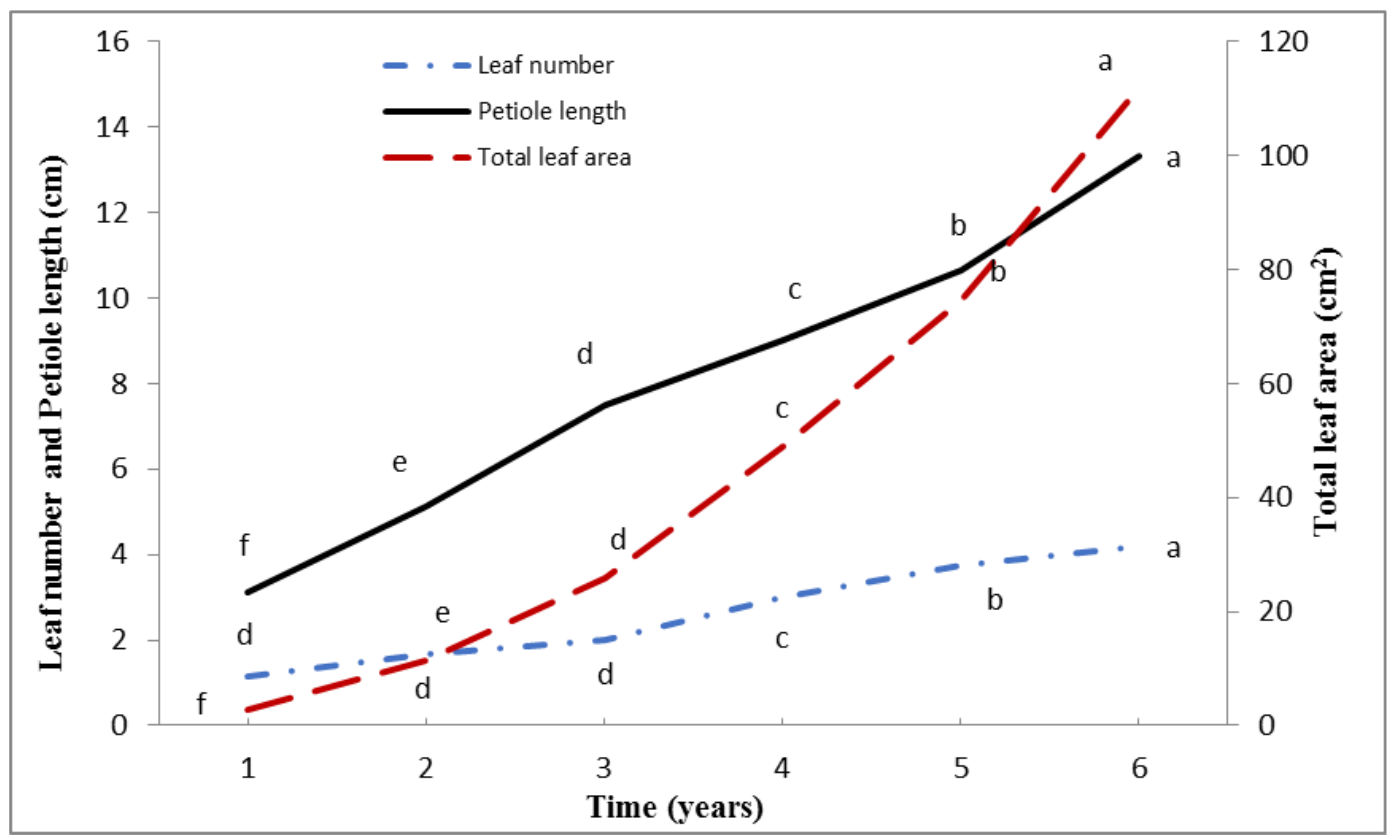

Figure 7. Annual increments of leaf number, total leaf area $\left(\mathrm{cm}^{2}\right)$ and petiole length $(\mathrm{cm})$ in the seedling of $C$. rohlfsianum during 6 years, in the Al-Bieda, East of Libya. Means with different letters above points are significantly different, according to Duncan's multiple range test,

$$
P=0.05
$$

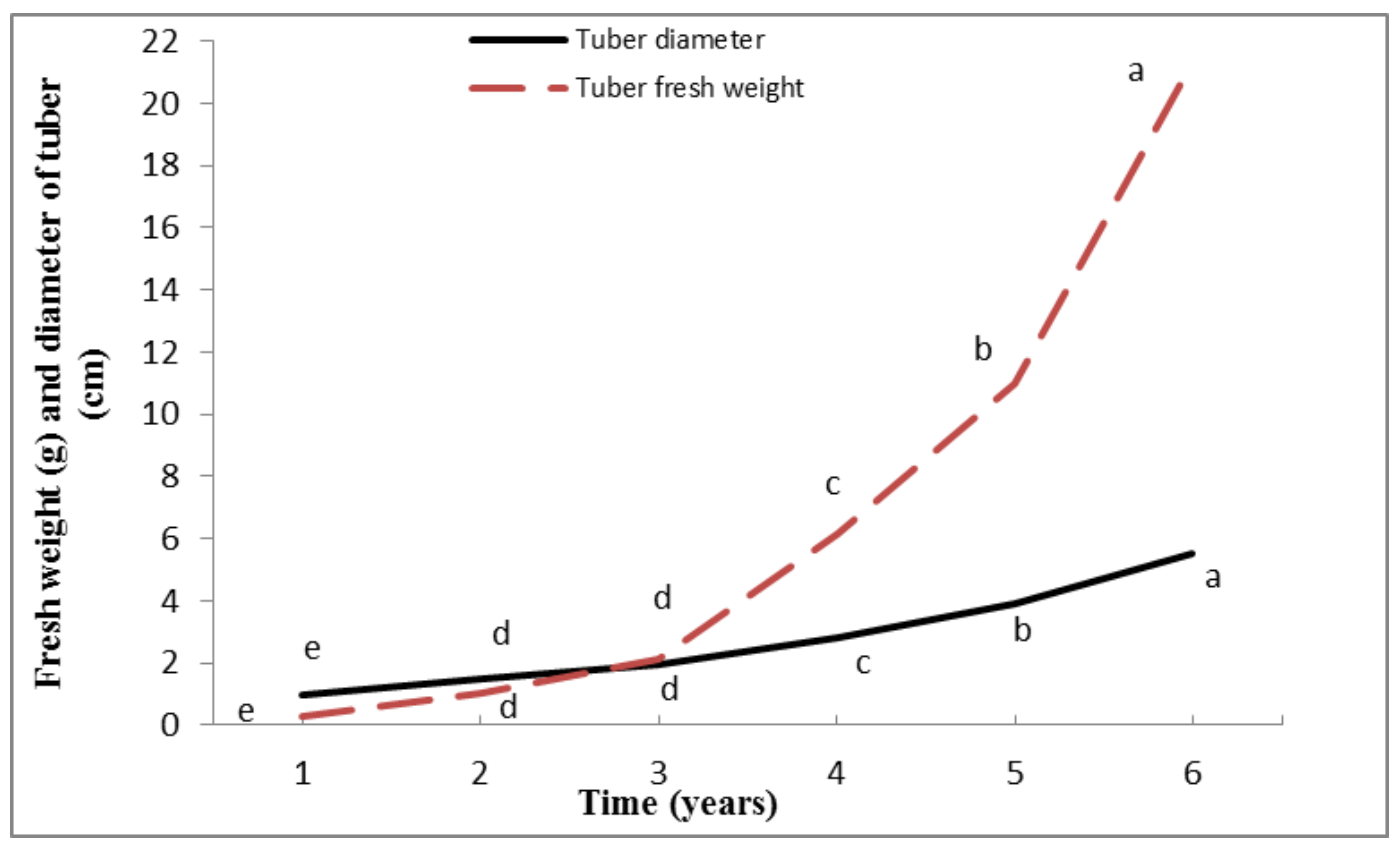

Figure 8. Annual increments of tuber fresh weight $(\mathrm{g})$ and diameter $(\mathrm{cm})$ in the seedling of Cyclamen rohlfsianum during 6 years, in the Al-Bieda, East of Libya. Means with different letters above points are significantly different, according to Duncan's multiple range test,

$$
P=0.05
$$


Following 4 years of vegetative growth, flowering began in the next growing season at early October, and $79 \pm 3.5 \%$ of plants flowered, with only $2.5 \pm 0.9$ flowers per plant. At 6-year-old plants, flowering began in late September and increased to $98 \pm 7 \%$, with $4.2 \pm 0.4$ flowers per plant. Similarly, length of petioles increased from $5.5 \pm 0.6 \mathrm{~cm}$ to $7.5 \pm 1.0 \mathrm{~cm}$, respectively (Table 1 ).

A fruit capsule had $15 \pm 4$ seeds. Seed fresh weight was $15.5 \pm 5 \mathrm{mg}$. The fruit capsule $(0.87 \pm 0.5 \mathrm{~g})$ color was green in November and changed to dark brown in late January.

Table 1. Percentage of flowering, time of flowering, number of flowers per plant and length of pedicel during six consecutive years from sowing to flowering tuber size of Cyclamen rohlfsianum

\begin{tabular}{c|c|c|c|c}
\hline Time (years) & $\begin{array}{c}\text { Percentage of } \\
\text { flowering (\%) }\end{array}$ & Time of flowering & $\begin{array}{c}\text { Number of } \\
\text { flowers/plant }\end{array}$ & $\begin{array}{c}\text { Length of pedicel } \\
\text { (cm) }\end{array}$ \\
\hline First to fourth & - & - & - & - \\
Fifth & $79 \pm 3.5$ & 2-5 October & $3.5 \pm 0.9$ & $5.5 \pm 0.6$ \\
Sixth & $98 \pm 7.0$ & $21-25$ September & $4.3 \pm 0.5$ & $7.5 \pm 1.0$ \\
\hline
\end{tabular}

Data expressed as mean \pm standard deviation $(n=54)$

\section{Discussion}

The vegetative propagation method of cyclamen by division or splitting of the tuber is difficult. Therefore, cyclamen is usually propagated by seeds (Fig. 5). Seed germination at $15^{\circ} \mathrm{C}$ and darkness are suitable for the optimum germination in many cyclamens (Neveur et al., 1986; Corbineau et al., 1989).

The pattern of $C$. rohlfsianum germination was fairly consistent with those of $C$. persicum, which was first described by Anderson and Widmer (1975) and Widmer (1992). They reported that, at 5 days old the primary root penetrates the soil, at 28 days old the fat hypocotyls are evident (tiny tubers), and at the last, cotyledon is emerged from the seed coat. However, the germination percentage was $90 \%$ or more but 80 to $85 \%$ was more common. Although, in the current study (Fig. 6), the germination percentage $(88 \pm 4 \%)$ was similar to that of $C$. persicum, there was a few days slower, in imbibition period and total germination period, than C. persicum.

Continued growth of the underground tuber, storage of food, and the production of the flower bud are dependent upon photosynthesis. Hence, plant at an earlier age of growth would be less able to sufficient accumulate reserves for increase in size of the tuber. Consequently, the photosynthetic area per plant has an important influence on accumulating reserves for increasing size of the tubers, which are properly large enough to produce flowers in the next year.

In this study, the tuber size (fresh weight and diameter) varied with age of plants, depending on number of leaves and leaf area. However, the time to produce flowers was based on tuber size. Hence, plant at an earlier age of growth would be less able to accumulate sufficient metabolites reserves for increasing size of the tuber. For example, number of leaves, total leaf area and tuber fresh weight were $1.16,2.85 \mathrm{~cm}^{2}$ and $0.29 \mathrm{~g}$ for 1-year-old plants, reached up to about 3.0, $49.0 \mathrm{~cm}^{2}$ and $6.15 \mathrm{~g}$ for 4-year-old plants (tuber flowering size for next growing season), up to $3.76,74.68 \mathrm{~cm}^{2}$ and $10.97 \mathrm{~g}$ for 5year-old plants, and then sharply increased to $4.21,111.78 \mathrm{~cm}^{2}$ and $21.27 \mathrm{~g}$, respectively for 6-year-old plants. However, the percentage of flowering, number of 
flowers and length of pedicle for 5-year-old plants $(79 \pm 3.5 \%, 3.5 \pm 0.9$ and $5.5 \pm 0.6 \mathrm{~cm}$, respectively) were lower than did 6-year-old plants $(98 \pm 7 \%$, $4.3 \pm 0.4$ and $7.5 \pm 1.0 \mathrm{~cm}$ ), which had a higher leaf number, leaf area and tuber size.

In some geophytes, the development of leaves is closely correlated with the initiation of flowers. A specific leaf number may be required before flower buds are initiated. In tulip, a flowering bulb produces three to five leaves, while a nonflowering bulb produces one leaf only. In the case of Dutch Iris, a vegetative plant can produce only one up to three leaves and, therefore, a knowledge of minimum leaf numbers for each species is vital information (Le Nard and De Hertogh, 1993b). Moreover, it is assumed that increasing in tuber size could be related to the increase in leaf number and area. Furthermore, the leaf number counted and total leaf area were related to initiation of flowers (Figs. 7 and 8).

The critical geophyte size can vary with the geophylic organ, genus, species, cultivar and the environmental conditions. However, above the critical size, flower production and quality often increase with size (Le Nard and De Hertogh, 2002). Therefore, tuber size is the major, and easily measured, factor that determining the capacity to flower. Moreover, the location of tuber is an important factor affecting the morphological traits of wild cyclamen by controlling the tuber size (Curuk, 2017).

These results are in agreement with those of Grey-Wilson (2002). He found that the high polyploidy species such as $C$. rohlfsianum $(2 \mathrm{n}=4 \mathrm{x}=96)$ are the slowest to reach flowering size from seed. It also requires about 4 to 5 years of vegetative growth to produce a flowering plant from a seedling. On the other hand, the seed propagated commercially important $C$. persicum and its cultivars, produced today, are expected to flower within 6-7 months from sowing (Widmer, 1992; Karlsson and Werner, 2001). Therefore, further researches are required to accelerate seedling development to maturity.

\section{Conclusion}

As a result, it is recommended for the grower to use the tuber size, which had at least three leaves, more than $3 \mathrm{~cm}$ diameter, or $6.15 \mathrm{~g}$ fresh weigh before planting to predict flowering in next growing season (5-year period). However, further increase in the tuber size is associated with increases in all the growth and flowering variables. It is obvious that further researches are needed to elucidate the influence of temperature, light and mineral elements on production of $C$. rohlfsianum, in order to reduce the time needed for tubers to reach flowering size when produced by growers, under protected cultivation.

\section{REFERENCES}

[1] Affre, L., Thomson, J. D. (1999): Variation in self-fertility, inbreeding depression and levels of inbreeding in four Cyclamen species. - J. Evolutionary Bio. 12(1): 113-122.

[2] Anderson, R. G., Widmer, R. E. (1975): Improving vigor expression of cyclamen seed germination with surface disinfestations and gibberellin treatment. - J. Amer. Soc. Hort. Sci. 100: 597-601.

[3] Corbineau, F., Neveur, N., Côme, D. (1989): Seed germination and seedling development in Cyclamen persicum. - Annals of Botany 63: 87-96. 
[4] Curuk, P. (2017): Impact of tuber location on morphological characteristics of cyclamen. - Pak. J. Bot. 49(1): 317-324.

[5] Curuk, P., Sogut, Z., Bozdogan, E., İzgu, T., Sevindik, B., Tagipour, E. M., Teixeira da Silva, J. A., Serce, S., Aka Kacar, Y., Yalcin Mendi, Y. (2015): Morphological characterization of Cyclamen sp. grown naturally in Turkey: Part I. - South Afr. J. Bot. 100: 7-15.

[6] Curuk, P., Sogut, Z., Izgu, T., Sevindik, B., Tagipur, E. M., Teixeira da Silva, J. A., Serce, S., Solmaz, I., Kacar, Y. A., Mendi, N. Y. Y. (2016): Morphological characterization of Cyclamen sp. grown naturally in Turkey: Part II. - Acta Sci. Pol. Hortorum Cultus 15(5): 205-224.

[7] Dole, J. M., Wilkins, H. F. (2005): Floriculture: Principles and Species. $2^{\text {nd }}$ Ed. - Pearson Education, Upper Saddle River, NJ, pp. 414-420.

[8] El-Darier, S. M., El-Mogaspi, F. M. (2009): Ethnobotany and relative importance of some endemic plant species at El-Jabal El-Akhdar Region (Libya). - World J. Agric. Sci. 5(3): 353-360.

[9] Grey-Wilson, C. (2002): Cyclamen. - Timber Press, Portland.

[10] Jackson, M. L. (1967): Soil Chemical Analysis. - Prentice-Hall of India, New Delhi.

[11] Jalali, N., Naderi, R., Shahi-Gharahlar, A., Teixeira da Silva, J. A. (2012): Tissue culture of Cyclamen spp. - Sci. Horticult. 137: 11-19.

[12] Karlsson, M., Werner, J. (2001): temperature affects leaf unfolding rate and flowering of cyclamen. - HortScience 36(3): 292-294.

[13] Lazarević, J., Lazarević, S. (2010): Possibilities for production and application of native Cyclamen neapolitanum in landscape architecture and horticulture. - Biol. Nyss. 1(1-2): 105-109.

[14] Le Nard, M., De Hertogh, A. A. (1993a): General Chapter on Spring Flowering Bulbs. In: De Hertogh, A. A., Le Nard, M. (eds.) The Physiology of Flower Bulbs. Elsevier, Amsterdam, pp. 750-740.

[15] Le Nard, M., De Hertogh, A. A. (1993b): Bulb Growth and Development and Flowering. - In: De Hertogh, A. A., Le Nard, M. (eds.) The Physiology of Flower Bulbs. Elsevier, Amsterdam, pp. 29-44.

[16] Le Nard, M., De Hertogh, A. A. (2002): Research needs for flower bulbs (geophytes). Acta Hort. 570: 113-120.

[17] Mammadov, R., Dusen, O., Ozay, C. (2016): Autoecological characteristics of Cyclamen mirabile Hildebr. (Primulaceae) - an endemic species of Turkey. - J. Res. Ecology 4(1): $1-9$.

[18] Muftuoglu, N. M., Altay, H., Sungur, A., Erken, K., Turkmen, C. (2009): Effects of different $\mathrm{N}, \mathrm{P}$, and $\mathrm{K}$ applications on the mineral contents of tuber and leaves of Cyclamen hederifolium plants. - Biol. Div. Conserv. 2(1): 21-26.

[19] Neveur, N., Corbineau, F., Côme, D. (1986): Some characteristics of Cyclamen persicum L. seed germination. - J. Hort. Sci. 61: 379-387.

[20] Oh, W., Rhie, Y., Park, J. H., Runkle, E. S., Kim, K. S. (2008): Flowering of cyclamen is accelerated by an increase in temperature, photoperiod, and daily light integral. - J. Hort. Sci. \& Bio. 83(5): 559-562.

[21] Rees, A. R. (1992): Ornamental Bulbs, Corms and Tubers. - CAB International, Wallingford.

[22] Seyring, M., Ewald, A., Mueller, A., Haensch, K. (2009): Screening for propagation suitability in vitro of different Cyclamen species. - Elec. J. Bio. 12(4): 1-10.

[23] Sibusawa, N., Ogawa, K. (1997): Production of interspecific hybrids between Cyclamen persicum Mill. and C. rohlfsianum Aschers. or C. persicum and C. libanoticum Hirdebr. Bull. Tokyo Agr. Exp. Stn. 27: 9-15.

[24] Snedecor, G. M., Cochran, W. G. (1980): Statistical Methods. $7^{\text {th }}$ Ed. - Iowa State Univ. Press, Ames. 
[25] Sundberg, M. D. (1981a): Apical events prior to floral evocation in Cyclamen persicum "F-1 Rosemunde" (Primulaceae). - Bot. Gaz. 142: 27-35.

[26] Sundberg, M. D. (1981b): The development of leaves and axillary flowers along the primary shoot axis of Cyclamen persicum "F-1 Rosemunde" (Primulaceae). - Bot. Gaz. 142: 214-221.

[27] Sundberg, M. D. (1982): Leaf initiation in Cyclamen persicum (Primulaceae). - Can. J. Bot. 60(11): 2231-2234.

[28] Takamura, T. (2007): Cyclamen. Cyclamen Persicum Mill. - In: Anderson, N. O. (ed.) Flower Breeding and Genetics Issues, Challenges and Opportunities. Springer, The Netherlands, pp. 459-478.

[29] Widmer, R. E. (1992): Cyclamen. - In: Larson, R. A. (ed.) Introduction to Floriculture. $2^{\text {nd }}$ Ed. Academic Press, Cambridge, MA, pp.385-407. 